\title{
FACTORS AFFECTING PROFITABILITY OF CONSTRUCTION COMPANY SUB-SECTOR
}

\author{
Wahana Halian*)1, Bonar M. Sinaga*), and Tanti Novianti**) \\ *) School of Business, IPB University \\ Jl. Raya Pajajaran, Bogor 16151, Indonesia \\ ${ }^{* *)}$ Departement of Economics , Faculty of Economics and Management, IPB University \\ Jl. Agatis, Campus IPB Dramaga Bogor 16680, Indonesia
}

\begin{abstract}
The increase is in construction activities is not always good considering that in the construction sub-sectors, the company is a long-term investment, and the payment is following the terms of project completion, causing a decrease in the company's profitability. This study aims to analyze the company's profitability in the construction subsector and the impact of the company's external and internal factors in the construction subsector. This study uses a simulation method with a simultaneous equation model consisting of seven simultaneous equations and six identity equations estimated using the 2SLS method (Two-Stage Least Squares). The Results Showed that if the gross domestic product fell by $4 \%$ and the cost of revenue decreased by $5 \%$, it resulted in an increase in return on assets by $12.95 \%$ (to $1.93 \% \mathrm{ROA}$ ) and returned on equity equal to 4.07 ( $R O E$ to $27.96 \%$ ). If inflation rises by $4 \%$ and the cost of revenue decreased by $5 \%$, it would increase is the return on assets by 12.79 (ROA to $1.92 \%$ ) and return on equity by $3: 52 \%$ (ROE to $27.81 \%$ ). If inflation rises by $4 \%$, the gross domestic product falls by $4 \%$, and cost of goods costs fall by $5 \%$, the resulting in an increase in return on assets by $9.61 \%$ (ROA to $1.87 \%$ ) and return on equity by $1.96 \%$ (ROE to $27.39 \%$ ).
\end{abstract}

Keywords: building construction subsector, external and internal factors, return on assets, return on equity, profitability, 2SLS

Abstrak: Peningkatan dalam kegiatan konstruksi tidak selalu baik mengingat bahwa dalam sub-sektor konstruksi, perusahaan adalah investasi jangka panjang, dan pembayarannya mengikuti persyaratan penyelesaian proyek, yang menyebabkan penurunan profitabilitas perusahaan. Penelitian ini bertujuan menganalisis profitabilitas perusahaan di subsektor konstruksi dan dampak faktor eksternal dan internal perusahaan di subsektor konstruksi. Penelitian ini menggunakan metode simulasi dengan model persamaan simultan yang terdiri dari tujuh persamaan simultan dan enam persamaan identitas yang diperkirakan menggunakan metode 2SLS (Two-Stage Least Squares). Hasil Menunjukkan bahwa jika produk domestik bruto turun $4 \%$ dan biaya pendapatan turun 5\%, itu menghasilkan peningkatan return on assets sebesar 12,95\% (menjadi 1,93\% ROA) dan returned on equity sebesar 4, 07 (ROE ke 27,96\%). Jika inflasi naik 4\% dan biaya pendapatan turun 5\%, yang akan meningkat adalah return on assets sebesar 12,79 (ROA menjadi 1,92\%) dan returned on equity sebesar 3: 52\% (ROE menjadi 27,81\%). Jika inflasi naik 4\%, produk domestik bruto turun 4\%, dan biaya pokok barang turun 5\%, yang mengakibatkan peningkatan return on assets sebesar 9,61\% (ROA menjadi 1,87\%) dan returned on equity s sebesar 1,96\% (ROE ke 27,39\%).

Kata kunci: subsektor konstruksi bangunan, faktor eksternal dan internal, return on assets, return on equity, profitabilitas, $2 S L S$

\footnotetext{
${ }^{1}$ Corresponding author:

Email: wahanahalian12@gmail.com
} 


\section{INTRODUCTION}

The increasingly dynamic economic circumstances require companies to evolve and adapt in competition constantly. The company's goal is to maintain the continuity, growth, and profitability. Profitability is an indicator of the company's performance in utilizing the entire wealth to generate profits. High levels of profitability reflect that the enterprises can work effectively and efficiently in their operations (Purnamasari, 2017). Based on data from the global ranking of logistics performance index (LPI) issued by the World Bank in 2018 condition of Indonesia's infrastructure is ranked (46), and Singapore (7), Thailand (32), and Malaysia (41). To support the activities of the acceleration of infrastructure development, the government raised the value of the state budget as in Figure 1.

Figure 1 provides information on the value of the state budget and can be seen every year from 2012 to 2016. The government granted the construction subsector budget increases. Values increased the state budget does not directly affect the company's earnings even though the value of the state budget continues to increase, but profitability, as reflected through the ROA and ROE, decreased in every year. According to Karim (2015), profitability represented by the Return On Equity (ROE) used to measure company effectivity in generating profits by utilizing existing capital. The higher the value Return On Equity (ROE) shows that companies are increasingly effective in using their working capital to generate profit that is planted by the investor into the company (Wahyu et al. 2013). Return On Asset (ROA) to measure a company's ability to generate net income based on the level of specific assets, ROA is also often referred to as Return On
Investment (ROI). the lower the value of this ratio, it can be said to be poor, and vice versa, so this ratio can be used as a gauge to measure the effectiveness of the entire operations of the company. (Mohammad, 2016). Internal, and external factors influence the company's profitability. The internal factor is anything within controlled by the company and can be analyzed using financial ratios as well as external factors. It includes macro-economic circumstances that occur, such as gross domestic product, inflation, interest rate, and exchange rate, so that the growth of the construction sector can be susceptible to macro-economic indicators (Dirgasiwi, 2016). While macroeconomic as external factors can also affect the performance and value of the company. Some macro-economic variables, such as high-interest rates, high inflation, and high exchange rate fluctuations, led to companies experiencing financial difficulties, which can reduce the financial performance, so the impact on the decline in the value of the company, Dwipartha (2013).

Profitability is the profit generated by the company. According to Saidi (2004), profitability is the company's ability to earn income. As a way to predict the future profitability of the company is to calculate financial ratios. Bank Indonesia use two ratios which depict the profitability of the corporate sector, the Return On Asset (ROA) and Return on Equity (ROE). ROA is a ratio between EBIT and total assets. It reflects the company's ability to generate profits with all ownedassets. Besides, the Return On Asset (ROA) is the ratio of total assets, which demonstrates the ability to generate profits after the deduction of interest and taxes andReturn On Equity (ROE) is a ratio used to measure a company's ability to generate profits by using their capital.

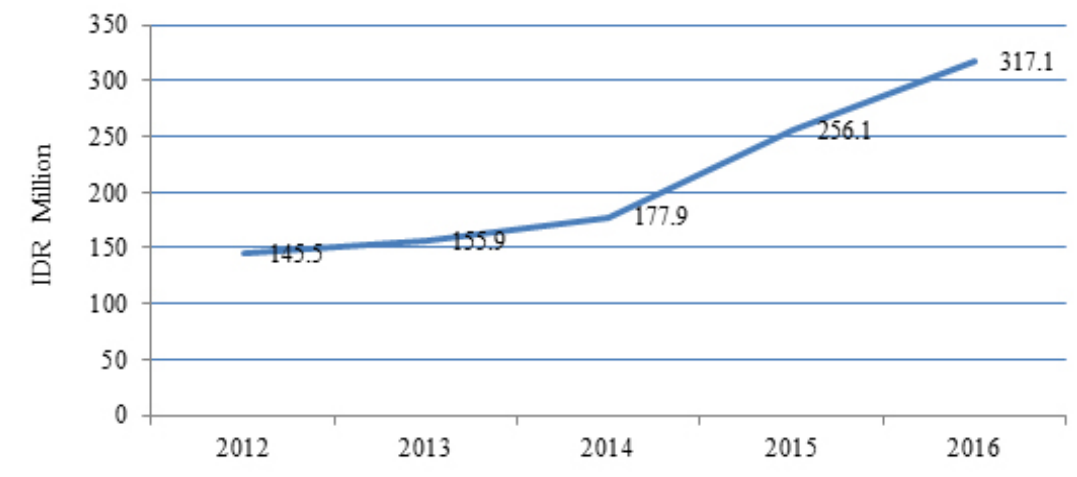

Figure 1. Increase in the value of infrastructure government revenue and expenditure budget Indonesia in 20122016 (Kemenkeu, 2017) 
Table 1 shows the general ratios Return on Assets (ROA) of the sub-sector building construction decreased in each year. The decline in this ratio is not good for the company, given the ROA is the ratio to predict the growth of corporate profits. ROA increasing in each period will describe the company's performance is getting better, so in other words, the larger the company ROA, the better, and vice versa (Hendrayani, 2014). This finding is consistent with Alfie (2016), where ROA increasing and positive means that the total assets of the company uses to operate the company can generate profits, and expected ROA is increasing every year. While ROE is the ratio used to measure a company's ability to generate profits by using its capital (Susiani, 2016).

Table 2 generally shows the value of Return On Equity (ROE) on building construction sub-sector company which is also decreased throughout the years from 2012 to 2016. The value of dwindling ROE is of course also not good for the company, according to Suryadie (2016) companies that have a low ROE or even negative, would be classifiable as a company less well in generating its income, while income rose it will affect the company's stock price has increased as well.

Table 1. Return on assets of the company from 2012 to 2016 year construction subsector

\begin{tabular}{lccccc}
\hline \multirow{2}{*}{ ISSUER } & \multicolumn{5}{c}{ YEAR } \\
\cline { 2 - 6 } & 2012 & 2013 & 2014 & 2015 & 2016 \\
\hline ADHI & $6: 30$ & $5: 00$ & $2: 24$ & $1: 15$ & 0.86 \\
DGIK & $1: 42$ & 0.76 & 2.88 & -0.14 & -3.67 \\
PTPP & $3: 06$ & 3.71 & $3: 48$ & $3: 54$ & $3: 05$ \\
SSIA & 14.68 & 9.98 & $6: 37$ & $6: 33$ & $2: 06$ \\
WSKT & 0.86 & $1: 17$ & -4.48 & -3.55 & $1: 15$ \\
\hline
\end{tabular}

Source: Indonesia Stock Exchange (2018)

Tabel 2. Return on equity firm construction subsector in 2012-2016

\begin{tabular}{lccccc}
\hline \multirow{2}{*}{ ISSUER } & \multicolumn{5}{c}{ YEAR } \\
\cline { 2 - 6 } & 2012 & 2013 & 2014 & 2015 & 2016 \\
\hline ADHI & 42.02 & 31.38 & $13: 38$ & 3.75 & $3: 18$ \\
DGIK & $2: 47$ & $1: 51$ & $5: 36$ & -0.27 & -7.51 \\
PTPP & 15.78 & $23: 18$ & 21.75 & $13: 22$ & 8.81 \\
SSIA & 42.68 & $22: 21$ & 12.69 & $12: 25$ & $4: 43$ \\
WSKT & $3: 59$ & $4: 33$ & -19.74 & -11.07 & $4: 20$ \\
\hline
\end{tabular}

Source: Indonesia Stock Exchange (2018)
The profit generated by a company is described by Saidi (2004) as the company's ability to earn income. Bank Indonesia use two ratios which depict the profitability of the corporate sector, the Return On Asset (ROA) and Return on Equity (ROE). ROA is the ratio of EBIT to total assets ratio and reflects the company's ability to generate profits with all assets owned by the company. According to Karim (2015), profitability represented by Return On Equity (ROE) used to measure company effectivity in generating profits by utilizing existing capital. The higher the value Return On Equity (ROE) shows that companies are increasingly effective in using their working capital to generate profit that is planted by the investor into the company (Wahyu et al. 2013).

Return On Asset (ROA) use to measure a company's ability to generate net income based on the level of specific assets. It is also often referred to as Return On Investment (ROI) the lower the value of this ratio, it can be said to be weak, and vice versa, so this ratio can be used as a measuring tool to measure the effectiveness of the entire operations of the company (Mohammad, 2016). Internal factors, and the internal-external influence the company's profitability. Internal factor is everything that can be controlled by the company. It can be analyzed using financial ratios, and external factors include macro-economic circumstances that occur, such as gross domestic product, inflation, interest rate, and exchange rate, so that the growth of the construction sector can be susceptible to macro-economic indicators (Dirgasiwi, 2016).

Barus and Leliani (2013) describes the simultaneous variable CR, TATO, DER, DR, and the size of the company's sales growth significantly affect the ROA. Partially only TATO, DR, and the size of companies have a significant effect on ROA. Macharia (2015) explains that the capital structure is negatively related to profitability (ROA). The size of the company has a positive relationship with profitability (ROA). Yani and Emrinaldi (2014) explained solvability ratio represented by the ratio of the partial LTDA does not affect stock returns. Profitability ratios represented by ROA and NPM, which partially have a significant influence on stock returns. Susiani (2016) explains that simultaneously have a significant impact on stock returns, but ROE, PBV, inflation and interest rates do not affect the return of partial stock. Return influenced by ROE, EPS, DER, PBV, inflation, and interest flower. 
Komara (2019) explains that hacyl simulation shows that the decline in international coal prices a major factor reduction company's financial performance, i.e. EBIT, PAT, and EVA. Harahap (2019) explains that the variable size, hpp, bua, sales, debt, and BIR influential for the company's financial performance, the company must make efficiency and look for cheap financing in the infrastructure sector, utilities, and transport. Additional research position as a reference related to internal and external analysis that can affect the performance of the company. Completion of the problems will be analyzed descriptively and statistics expected to undefined in comprehensive.

The research objective is to analyze: (1) the company's profitability building construction subsector, and (2) the impact of external and internal factors on the profitability of companies sub-sector construction. The scope of the company's profitability study of building construction sub-sector assessed using the Return on Assets and Return on Equity. Companies surveyed as many as five (5) sub-sector construction companies listed on the Indonesia Stock Exchange year period 2012-2016. The data used is the data panel.

\section{METHODS}

The study uses a quantitative approach which describes a statistical fact or phenomenon and shows the relationship between these facts by using an econometric model. The first objective was analyzed using a model system of recursive equations, study, using a model system of equations that has been done by Muhammad (2019) and Priadi (2019) in the form of the recursive equation system.

The data used is the data taken from the panel statement of comprehensive income, statement of financial position, statement of cash flows, and notes to the financial statements, which are issued by companies listed construction sub-sector in Indonesia Stock Exchange (BEI) in 2012-2016. Data accessed throughwww.idx.co.id and other websites to complete the research data, including www.bi.go.id, www.bps. go.id., Companies selected as Five (5) sub-sector construction company Adhi Karya (ADHI), Nusa Konstruksi Engineering (DGIK), Pembangunan Perumahan (PTPP), Surya Semesta Internusa (SSIA), dan Waskita Karya (WSKT). Diagram linkages between variables in the model of the company's profitability sub-sector building construction presented in Figure 2. The econometric model specification in the form of a system of simultaneous equations, as follows:

Civil income (PSP)

$\operatorname{PSP}_{\text {it }}=\mathrm{a}_{0}+\mathrm{a}_{1}\left(\mathrm{GDP}_{\mathrm{it}}-\mathrm{GDP}_{\mathrm{it}-1}\right)+\mathrm{a}_{2} \mathrm{INF}_{\mathrm{it}-1}+\mathrm{a}_{3} \mathrm{IRT}_{\mathrm{it}}+$ $\mathrm{a}_{4} \mathrm{EXR}_{\mathrm{it}}+\mathrm{a}_{5} \mathrm{PSP}_{\mathrm{it}-1}+\mathrm{U}_{\text {lit }}$

Estimation parameter sign expected: $\mathrm{a}_{1}, \mathrm{a}_{4}>0$; $\mathrm{a}_{2}, \mathrm{a}_{3}<0 ; 0<\mathrm{a}_{5}<1$

Revenue building (PBG)

$$
\begin{aligned}
\mathrm{PBG}_{\mathrm{it}}= & \mathrm{b}_{0}+\mathrm{b}_{1} \mathrm{GDP}_{\mathrm{it}-1}+\mathrm{b}_{2} \mathrm{INF}_{\mathrm{it}}+\mathrm{b}_{3} \mathrm{IRT}_{\mathrm{it}-1}+\mathrm{b}_{4} \mathrm{EXR}_{\mathrm{it}}+ \\
& \mathrm{b}_{5} \mathrm{PBG}_{\mathrm{it}-1}+\mathrm{U}_{2 \mathrm{it}} \\
& \text { Estimation parameter sign expected: } \mathrm{b}_{1}, \mathrm{~b}_{2}, \mathrm{~b}_{4}> \\
& 0 ; \mathrm{b}_{3}<0 ; 0<\mathrm{b}_{5}<1
\end{aligned}
$$

Total company revenues (TPP)

$$
\mathrm{TPP}_{\mathrm{it}}=\mathrm{PSP}_{\mathrm{it}}+\mathrm{PBG}_{\mathrm{it}}
$$

Operate cost company (BOP)

$$
\mathrm{BOP}_{\mathrm{it}}=\mathrm{BUA}_{\mathrm{it}}+\mathrm{BPM}_{\mathrm{it}}
$$

Gross profit company (LKP)

$$
\mathrm{LKP}_{\mathrm{it}}=\mathrm{TPP}_{\mathrm{it}}-\mathrm{BPP}_{\mathrm{it}}
$$

Earnings before interest and tax (EBIT)

$$
\begin{aligned}
\mathrm{EBIT}_{\mathrm{it}}= & \mathrm{c}_{0}+\mathrm{c}_{1} \mathrm{LKP}_{\mathrm{it}}+\mathrm{c}_{2}\left(\mathrm{BOP}_{\mathrm{it}}-\mathrm{BOP}_{\mathrm{it}-1}\right)+\mathrm{U}_{3 \mathrm{it}} \\
& \text { Estimation parameter sign expected: } \\
& \mathrm{c}_{1}>0 ; \mathrm{c}_{2}<0
\end{aligned}
$$

Interest expense company (BBP)

$$
\mathrm{BBP}_{\mathrm{it}}=\mathrm{d}_{0}+\mathrm{d}_{1} \mathrm{TLP}_{\mathrm{it}}+\mathrm{d}_{2} \mathrm{BBP}_{\mathrm{it}-1}+\mathrm{U}_{4 \mathrm{it}}
$$

Sign of the expected parameters: $d_{1}>0$

Net income company (LBP)

$$
\begin{aligned}
\mathrm{LBP}_{\mathrm{it}}= & \mathrm{e}_{\mathrm{o}}+\mathrm{e}_{1} \mathrm{EBIT}_{\mathrm{it}}+\mathrm{e}_{2} \mathrm{BBP}_{\mathrm{it}-1}+\mathrm{e}_{3} \mathrm{BPJ}_{\mathrm{it}}+\mathrm{e}_{4} \mathrm{LBP}_{\mathrm{it}-1}+ \\
& \mathrm{U}_{4 \mathrm{it}} ; \text { Sign of the expected parameters: } \mathrm{e}_{1}>0 ; \\
& \mathrm{e}_{2}, \mathrm{e}_{3}<0 ; 0<\mathrm{e}_{4}<1
\end{aligned}
$$

Total company assets (TAP)

$$
\mathrm{TAP}_{\mathrm{it}}=\mathrm{ALP}_{\mathrm{it}}+\mathrm{ATL}_{\mathrm{it}}
$$


Total liability company (TLP)

$\operatorname{TLP}_{\mathrm{it}}=\operatorname{LJP}_{\mathrm{it}}+\mathrm{LJJ}_{\mathrm{it}}$

Return on assets (ROA)

$\mathrm{ROA}=\mathrm{f}_{0}+\mathrm{f}_{1}\left(\mathrm{LBP}_{\mathrm{it}}-\mathrm{LBP}_{\mathrm{it}-1}\right)+\mathrm{f}_{2} \mathrm{TAP}_{\mathrm{it}}+\mathrm{U}_{5 \mathrm{it}} ;$ Estimation parameter sign expected (Hypothesis): $f_{1}>0 ; f_{2}$ $<0$

Total equity company (TEP)

$\mathrm{TEP}_{\mathrm{it}}=\mathrm{MDP}_{\mathrm{it}}+\mathrm{TMD}_{\mathrm{it}}+\mathrm{SLP}_{\mathrm{it}}$

Return on equity (ROE)

$\mathrm{ROE}=\mathrm{g}_{0}+\mathrm{g}_{1} \mathrm{LBP}_{\mathrm{it}-1}+\mathrm{g}_{2}\left(\mathrm{TEP}_{\mathrm{it}}-\mathrm{TEP}_{\mathrm{it}-\mathrm{1}}\right)+\mathrm{U}_{6 \mathrm{it}} ;$ Estimation parameter sign expected (Hypothesis): $\mathrm{g}_{1}>0 ; \mathrm{g}_{2}$ $<0$

A conceptual framework to determine how the impact of macroeconomic and corporate policies on the profitability of the construction sub-sector in 20122016 presented in Figure 2. The state of the increasingly dynamic economy requires companies to be able to maintain its profitability, profitability measured by the ratio of return on assets (ROA ) and return on equity (ROE) in the building construction sub-sector company ROA, and ROE decreased in every year, and this became a problem for the company because the company is good is if the ROA and ROE increased in every year. The company's profitability is affected by macroeconomic covers gross domestic product, inflation, interest rate, and exchange rate policy while the company includes the cost of revenues.

Model studies reviewed in this study supported by an explanation using several variables. It intended to make clear from the purpose of the research undertaken. Here is a list of endogenous and exogenous variables used in the research model, the impact of external and internal factors on the profitability of the company building construction subsector presented in Table 3.

Model building construction sub-sector company's profitability is estimated using the software Statistical Analysis System/Econometric Time Series (SAS / ETS), with stages 1) Before the parameter estimation stage is identification in each structural equation model. 2) The identification result is Over Identified models, and the model is estimated using Two-Stage Least Squares (2SLS). 3) Before the simulation stage the impact of external and internal factors, model validation using criteriaTheil's Inequality Coefficient (U-Theil).

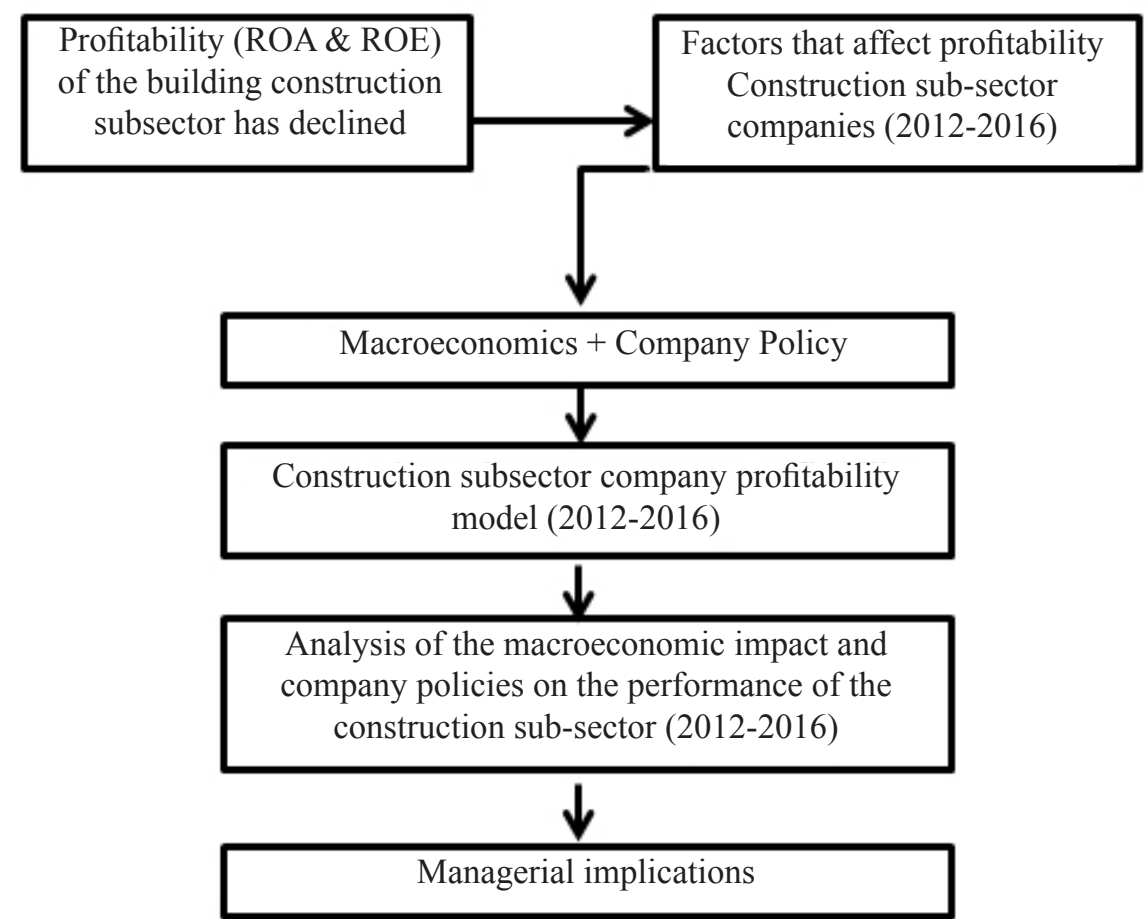

Figure 2. Research framework 
Table 3. List of endogenous and exogenous variables used in the model

\begin{tabular}{lcl}
\hline \multicolumn{1}{c}{ Variables } & $\begin{array}{c}\text { The type } \\
\text { of data }\end{array}$ & Unit \\
\hline Endogenous & internal & million \\
Civil income & internal & million \\
revenue Building & internal & million \\
Total income & internal & million \\
Gross profit & internal & million \\
Net profit & internal & million \\
EBIT & internal & million \\
Operating Expenses & internal & million \\
total Assets & internal & million \\
total Liabilities & internal & million \\
total Equity & internal & ratios \\
Return on Assets & internal & ratios \\
Return on Equity & & \\
Exogenous & external & ratios \\
Gross Domestic Product & external & ratios \\
Inflation & external & ratios \\
interest Rate & external & ratios \\
Exchange Rate & internal & million \\
Cost of Revenue & internal & million \\
Marketing Expenses & internal & million \\
General Administrative Expenses & internal & million \\
Interest Expense The Company & internal & million \\
Current assets & internal & million \\
Current Assets & internal & million \\
Short-term liabilities & internal & million \\
Long-Term Liabilities & internal & million \\
Paid-up capital & internal & million \\
Additional Paid in Capital & internal & million \\
Retain earning & internal & million \\
Tax expense & & \\
\hline & &
\end{tabular}

The scenario simulated the impact of external (gross domestic product, inflation, interest rate and exchange rate) and internal factors (cost of revenue, general, and administration expenses and marketing expenses) toward the profitability of companies sub-sector construction. The scenario held as follows 1) The first scenario is gross domestic product dropped by $4 \%$, and the exchange rate against the USD depreciated by $10 \%$. 2) The second scenario is on condition inflation rose by $4 \%$, and the exchange rate against the USD depreciated by $10 \%$. 3) The third scenario is the interest rate conditions rose 1 point, and the exchange rate depreciated by $10 \%$. 4) The fourth scenario is the condition of the gross domestic product dropped by $4 \%$, and the cost of revenues declined $5 \%$. 5) The fifth scenario is at $4 \%$ when inflation is rising, and the cost of revenues declined 5\% 6) The sixth scenario is at $4 \%$ when inflation is rising, gross domestic product dropped by $4 \%$, and the cost of revenues declined $5 \%$

\section{RESULTS}

\section{Construction Companies Sub-Sector Profitability}

Building construction sub-sector company's profitability assessed using the Return on Assets (ROA) and Return on Equity (ROE), the higher the ROA and ROE, the better. ROA and ROE building construction subsector declined every year. The external factors that cause a decline in ROA and ROE derived from macroeconomic factors such as interest rate hikes. External conditions that make the company pay higher interest on loans to banks, considering the majority of the company's funds sourced from bank loans. Then it makes the company's profitability decline seen from the ROA and ROE. Internal factors causing the decline in ROA and ROE is a company's net profit declined every year,

\section{Model Estimation Results profitability of the Company Sub Sector Construction}

Econometric model profitability of companies subsector building construction in the research constructed of 13 equations. The equations consist of structural equations 7 and 6 identity equation. The model has been through several stages respecified models. Generally, all of the explanatory variables are incorporated into the structural equations have a mark in line with expectations, especially seen from economic theory. A standard statistical criteria used in evaluating the results of model estimation is quite convincing.

\section{Profitability Model Validation Results Sub Sector Construction Company}

The results of the company's profitability model validation construction sub-sectors showed $61.53 \%$ of the endogenous variables U-Theil have coefficient value under $0: 50$ and $38.47 \%$ in value over $0: 50$. This finding shows that during the observation period, the year 2012-2016 is an estimated fairly good model used for the simulation of alternative internal and external factors impact on the profitability of companies subsector construction. 
External and Internal Factors impact on the profitability of the Company Sub Sector Construction

After the model of the company's profitability in the building construction sub-sector validation, the next is to perform simulations impact scenarios. It is intended as information to determine the internal and external relationships to the profitability of the construction sub-sector company. Here are presented six alternative scenarios for simulation of internal and external factors impact on the profitability of companies sub-sector building construction, as shown in Table 4.

Table 4 shows if the drop in Gross Domestic Product by $4 \%$ and the exchange rate depreciated by $10 \%$ impact on improving the return on assets amounted to $185.98 \%$ (ROA becomes 4.96\%) and an increase in return on equity amounted to $98.64 \%$ (ROE became $53.37 \%$ ). If the rise in inflation was $4 \%$ and the exchange rate depreciated by a $10 \%$ impact on the increase of 185.81 Return On Asset (ROA becomes 4.88\%) and Return On Equity amounted to 98.10 (ROE became 53.22\%). If the rise in interest rate by 1 point and the exchange rate depreciated by a $10 \%$ impact on improving the return on assets of $29.01 \%$ (ROA be $2: 20 \%$ ) and increase Return On Equity of 16:32\% (ROE became 31.25\%). If Gross Domestic Product fell by $4 \%$ and the cost of revenue decreased by $5 \%$ impact on improving the return on assets of $12.95 \%$ (ROA becomes 1.93\%) and Return On Equity at 4:07\% (ROE became 27.96\%). If inflation is up by $4 \%$ and the cost of revenue decreased by $5 \%$ impact on improving the return on assets of $12.79 \%$ (ROA becomes 1.92\%) and Return On Equity at 3:52\% (ROE became $27.81 \%$ ). If inflation is up by $4 \%$, Gross Domestic Product fell by $4 \%$. The cost of revenues declined $5 \%$, impact on improving the return on assets amounted to $9.61 \%$ (ROA becomes $1.87 \%$ ) and Return On Equity amounted to 1.96\% (ROE became 27.39\%), If inflation is up by $4 \%$ and cost of revenue decreased by $5 \%$ impact on improving the return on assets of $12.79 \%$ (ROA becomes 1.92\%) and Return On Equity at $3: 52 \%$ (ROE became $27.81 \%$ ). If inflation is up by $4 \%$, Gross Domestic Product fell by 4\%. The cost of revenues declined 5\%, impact on improving the return on assets amounted to $9.61 \%$ (ROA becomes $1.87 \%$ ) and Return On Equity amounted to $1.96 \%$ (ROE became $27.39 \%$ ), If inflation is up by $4 \%$ and cost of revenue decreased by $5 \%$ impact on improving the return on assets of $12.79 \%$ (ROA becomes $1.92 \%$ ) and Return On Equity at 3:52\% (ROE became 27.81\%). If inflation is up by $4 \%$, Gross Domestic Product fell by $4 \%$, and the cost of revenues declined 5\%, impact on improving the return on assets amounted to $9.61 \%$ (ROA becomes $1.87 \%$ ), and Return On Equity amounted to $1.96 \%$ (ROE became $27.39 \%$ ).

Table 4. Impact of external and internal factors on the profitability of companies sub-sector building construction

\begin{tabular}{ccccccccc}
\hline \multirow{2}{*}{ Endogenous variables } & \multirow{2}{*}{ Unit } & \multicolumn{5}{c}{ Basic Value } & \multicolumn{5}{c}{ Impact of Simulation Scenarios $(\%)$} \\
\cline { 5 - 9 } & & & S1 & S2 & S3 & S4 & S5 & S6 \\
\hline PSP & Million / USD & $9,692,936$ & 30.77 & 28.63 & 10.96 & -0.09 & -2.23 & -2.32 \\
PBG & Million / USD & $2,046,438$ & 151.12 & 159.81 & -3.06 & -4.34 & $4: 35$ & $0: 01$ \\
TPP & Million / USD & $11,739,374$ & 51.75 & 51.50 & $8: 52$ & -0.83 & -1.08 & -1.91 \\
LKP & Million / USD & $4,206,695$ & 144.42 & 143.71 & 23.77 & 6.64 & 5.93 & 3.61 \\
BOP & Million / USD & 387.471 & $0: 00$ & $0: 00$ & $0: 00$ & $0: 00$ & $0: 00$ & $0: 00$ \\
EBIT & Million / USD & $3,464,054$ & 154.65 & 153.88 & 25.45 & $7: 11$ & $6: 35$ & 3.87 \\
TLP & Million / USD & $9,572,213$ & $0: 00$ & $0: 00$ & $0: 00$ & $0: 00$ & $0: 00$ & $0: 00$ \\
BBP & ratios & 220.331 & $0: 00$ & $0: 00$ & $0: 00$ & $0: 00$ & $0: 00$ & $0: 00$ \\
LBP & Million / USD & $3,031,085$ & 176.74 & 175.87 & 29.08 & $8: 12$ & $7: 25$ & $4: 42$ \\
TAP & Million / USD & $14,036,003$ & $0: 00$ & $0: 00$ & $0: 00$ & $0: 00$ & $0: 00$ & $0: 00$ \\
ROA & Million / USD & 2 & 185.98 & 185.81 & 29.01 & 12.95 & 12.79 & 9.61 \\
TEP & ratios & $3,394,497$ & $0: 00$ & $0: 00$ & $0: 00$ & $0: 00$ & $0: 00$ & $0: 00$ \\
ROE & ratios & 27 & 98.64 & 98.10 & $16: 32$ & $4: 07$ & $3: 52$ & 1.96 \\
\hline
\end{tabular}




\section{Managerial Implications}

To improve the profitability of the company (retun on assets and return on equity) sub-sector of the building construction. The companies advised to reduce the cost of revenue by doing increased efficiency of materials management, oversee the activities of workers in terms of project completion, and minimize rents from machinery and equipment. To increase stock returns in companies sub-sector construction, investors advised to be more careful on the conditions, especially the increase in interest rate which greater impact on lowering the company's profitability.

\section{CONCLUSIONS AND RECOMMENDATIONS}

\section{Conclusions}

The impact of external factors subsectors building constructioni.e. if the conditions decrease gross domestic product by $4 \%$ and the exchange rate depreciated by $10 \%$ impact on improving the return on assets amounted to $185.98 \%$ (ROA becomes $4.96 \%$ ) and an increase in return on equity of $98.10 \%$ (ROE became $53.37 \%$ ). If the condition of a $4 \%$ rise in inflation and the exchange rate depreciated by a $10 \%$ impact on the increase of 185.81 Return On Asset (ROA becomes 4.88) and Return On Equity amounted to 98.10 (ROE became 53.22). If the condition of the increase in interest rate by 1 point and the exchange rate depreciated by $10 \%$ impact on improving the return on assets of $29.01 \%$ (ROA be 2:20\%) and increase Return On Equitysebesar $16: 32 \%$ (ROE became 31.25). Furthermore, the impact of external factors and internal sub-sector of building construction that is if the gross domestic product fell by $4 \%$ and cost of revenue decreased by $5 \%$ impact on improving the return on assets of $12.95 \%$ (ROA becomes 1.93\%) and Return On Equity at 4:07 (ROE became $27.96 \%$ ). If inflation is up by $4 \%$ and the cost of revenue decreased by $5 \%$ impact on the increase of 12.79 Return On Asset (ROA becomes 1.92\%) and Return On Equity at 3:52\% (ROE became 27.81\%). If inflation is up by $4 \%$, Gross Domestic Product fell by $4 \%$, and the cost of revenues declined $5 \%$, impact on improving the return on assets amounted to $9.61 \%$ (ROA becomes $1.87 \%$ ), and Return On Equity amounted to $1.96 \%$ (ROE became $27.39 \%$ ).

\section{Recommendations}

For further research supplement the limitations of this study. To the company, the company subsector construction is a long-term investment and cash turnover that long, so companies are advised to periodically manage the financial statements properly and consider the ratio of profitability and debt. This study suggests several further research, namely: (1) Using all the samples listed companies are not only building construction subsector, (2) Include other variables that affect earnings quality, such as the organization of working capital, operating cycles and corporate debt by using all samples of the issuer, not only the building construction subsector.

\section{REFERENCES}

[BEI] Bursa Efek Indonesia. 2016. Laporan keuangan dan tahunan. http://www.idx. co.id/idid/beranda/perusahaantercatat/ laporankeuangandantahunan.aspx. $\quad\left[\begin{array}{ll}18 & \text { Jan }\end{array}\right.$ 2019].

Dirgasiwi FD, Dewi SA, Gustyana TT. 2016. Pengaruh Inflasi, Nilai tukar Mata Uang, ROA, dan DER Terhadap Return Saham Perusahaan Subsektor Konstruksi Periode 2011-2015. Jurnal E-Proceeding of Management 3(3):1-11. https:// doi.org/10.35137/jmbk.v3i3.16.

Dwipartha NMW. 2013. Pengaruh faktor ekonomi makro dan kinerjakeuangan terhadap nilai perusahaan manufaktur di Bursa Efek Indonesia. Jurnal Ekonomi dan Bisnis 2(4):226-248.

Harahap M. 2019. Dampak faktor eksternal dan internal terhadap effective tax rate perusahaan sektor infrastruktur, utilitas dan transportasi di bursa efek Indonesia [Disertation]. Bogor: Institut Pertanian Bogor

Hendrayani E. 2014. Pengaruh rasio Keuangan dan Ukuran Perusahaan Terhadap Return Saham Pada Perusahaan Jasa Konstruksi Bursa Efek Indonesia. Jurnal Tepak Manajemen Bisnis 6 (1):33.

Karim A. 2015. Analisis pengaruh faktor internal dan eksternal terhadap return saham perusahaan manufaktur yang terdaftar di Bursa Efek Indonesia (BEI) periode 2010-2012. Jurnal Media Ekonomi dan Manajemen 30(1):45.

[Kemenkeu] Kementrian keuangan. 2017. Perekonomian Indonesia dan APBN 2017. 
https://www.kemenkeu.go.id/apbn2017.[16 Feb2018].

Komara AA. 2019. Dampak faktor eksternal dan internal terhadap kinerja keuangan dan return perusahaan tambang batubara [thesis]. Bogor: Institut Pertanian Bogor.

Macharia ME. 2016. The relationship between capital structure and profitability of construction and allied firms listed at the Nairobi securities exchange[thesis]. Nairobi: University of Nairobi.

Muhammad RR. 2019. Dampak faktor eksternal dan internal terhadap fleksibilitas keuangan perusahaan batubara [thesis]. Bogor: Institut Pertanian Bogor.

Muhammad YE. 2016. Analisis faktor-faktor Yang mempengaruhi profitabilitas pada perusahaan telekomunikasi.JurnalIlmudanRiset Manajemen 5(6):57-72. https://doi.org/10.21831/nominal. v4i2.8000.

Priadi RA. 2019. Dampak faktor eksternal dan internal terhadap financial distress perusahaan manufaktur go public sub sektor makanan dan minuman tahun 2008-2017 [thesis]. Bogor: Institut Pertanian Bogor.

Purnamasari ED. 2017. Analisis pengaruh laverage terhadap profitabilitas perusahaan yang termasuk dalam LQ45 periode agustus 2015 - januari 2016 di Bursa efek Indonesia. Jurnal Ilmiah Ekonomi Global Masa Kini 8(1):39.

Saidi. 2004. Faktor-faktor yang mempengaruhi struktur modal pada perusahaan manufaktur go public di BEJ tahun 1997-2002. Jurnal Bisnis dan Ekonomi 11(1):44-58.

Suryadie FS. 2016. Pengaruh tingkat inflasi, nilai tukar rupiah, suku bunga, return on equity (roe), dan return on asset (roa) terhadap harga saham. [thesis]. Pasuruan Universitas Pasuruan.

Susiani. 2016. Analisis pengaruh faktor- faktor internal dan eksternal terhadap return saham pada perushaan properti dan real estate yang terdaftar di Bursa Efek Indonesia periode 2012-2014. Jurnal Media Mahardhika 12(3):330-334.

Yani H, Emrinaldi. 2014. Pengaruh rasio keuangan dan ukuran perusahaan terhadap return saham pada perusahaan jasa konstruksi Bursa Efek Indonesia. Jurnal Tepak Manajemen Bisnis 6 (1):31-39. 